\title{
Business backlash kills off software meeting
}

\section{Declan Butler}

Lobbying by US business interests has shot down a proposed meeting, to be held by the Geneva-based World Intellectual Property Organization (WIPO) next year, to explore 'open' models of innovation.

A group of leading scientists and economists suggested the meeting in a 7 July letter to Kamil Idris, director-general of WIPO. They highlighted the explosion of various open and collaborative projects to create public goods, such as the Human Genome Project and opensource software, and said it was time for WIPO to include the approach in its deliberations.

Francis Gurry, assistant director-general and legal counsel at WIPO, told Nature at the time that the agency welcomed the idea as "a very important and interesting development". He added that "the director-general looks forward with enthusiasm to taking up the invitation to organize a conference to explore the scope and application of these models" (see Nature 424, 118; 2003).

But Gurry's words seem to have triggered a backlash from firms that would rather see WIPO working to protect their intellectual property rights. Gurry says WIPO has since been inundated with calls from trade and consumer groups and government representatives. It is understood that lobbyists such as the Business Software Alliance, which is partly funded by Microsoft, also pressed the US state department and the US Patent and Trademark Office to have the meeting called off. US government officials have since spoken out against the idea.

"The request for an open discussion on a range of projects became transformed into a domestically, as opposed to internationally, polarized debate about just one 'project': opensource software," says Gurry. As a result, he says, the meeting is now unlikely to take place.

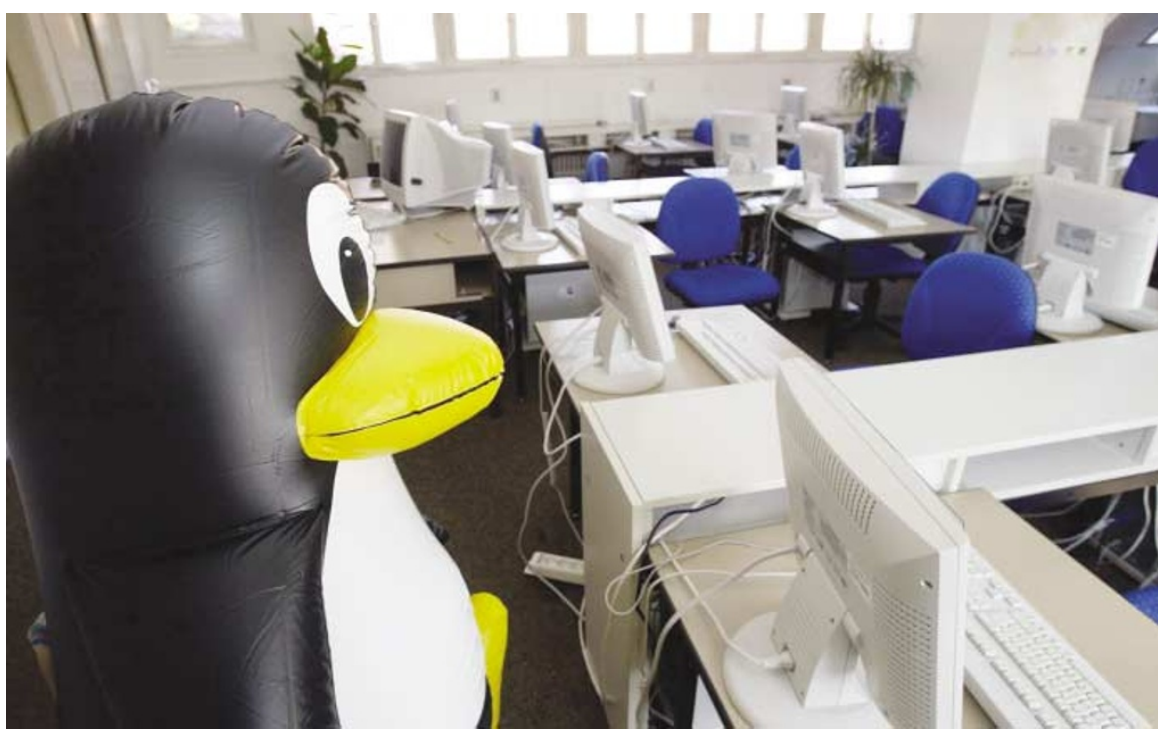

Empty seats: lobbying means the Linux penguin will not witness a discussion of intellectual property.

"The possibility of conducting a policy discussion on intellectual property of the sort appropriate for an international organization became increasingly remote," he claims.

In the United States, the European Union and elsewhere, governments are considering measures to encourage the public procurement of open-source software, such as the Linux operating system. This is being vigorously opposed by some software companies and by the Business Software Alliance.

Economist Paul David of Stanford University in California, who signed the letter, says he is "appalled" that the meeting should be "scuttled because of the mere presence of opensource software in a list of many other forms of collaborative knowledge production".

But Lois Boland, director of international relations for the US Patent and Trademark
Office, says that open-source software is contrary to WIPO's mission to promote intellectual property rights. "To hold a meeting to disclaim or waive such rights seems to us to be contrary to the goals of WIPO," she says.

The Washington-based Computer and Communications Industry Association, which represents small companies that support open-source software, has attacked WIPO's decision not to hold the meeting. Edward Black, president of the group, says that the association has written to Boland to complain about her comments.

Tim Hubbard, a genomicist at the Sanger Institute near Cambridge, UK, and a signatory to the letter, says he is still hopeful that the meeting may happen. "It's not the role of industries regulated by such regimes to inhibit discussion," he argues.

\section{Biophysicist named to run basic-research arm of $\mathrm{NIH}$}

Erika Check, Washington

The US National Institute of

General Medical Sciences

(NIGMS) - the arm of the

National Institutes of Health

that focuses on basic research

- has named its next director.

Jeremy Berg, head of

biophysics and biophysical

chemistry at Johns Hopkins

University School of Medicine

in Baltimore, Maryland, will

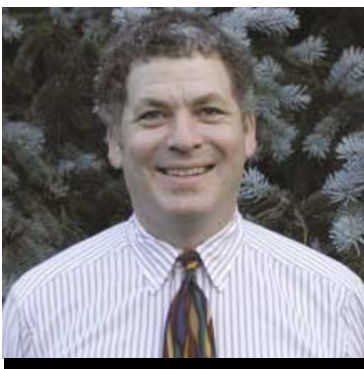

Jeremy Berg: varied approach.
Berg says he aims to find the right mix of investigatorinitiated research and largescale projects, including collaborative grants in areas such as cell signalling. "The spirit of investigatorinitiated, curiosity-driven research has been what NIGMS is all about," he says. "But there are clearly advantages to large projects, take up the post in November. He succeeds Marvin Cassman, who left in May 2002 to head the Institute for Quantitative Biomedical Research, a biology lab at the University of California, San Francisco. so there has to be a balance."

Berg also professes a strong interest in training young scientists, and in the multiinstitute projects planned by National Institutes of Health (NIH) director Elias
Zerhouni. He says that his previous work with Zerhouni, who was executive vice-dean at Johns Hopkins medical school before coming to the NIH, was an incentive for him to take the post at the NIGMS.

With an annual budget of more than $\$ 1.8$ billion, the NIGMS is one of the world's largest supporters of lab-based biological research. Unlike most branches of the NIH, it has no disease-specific remit but instead backs basic science in areas such as cell biology.

Berg's own research focuses on the structure and function of proteins, and in particular on how proteins recognize their target destinations. He plans to take his laboratory with him to the NIH campus in Bethesda, Maryland. 